\title{
Effect of a resistance exercise program for sarcopenic elderly women: quasi-experimental study
}

\author{
Efeito de um programa de exercícios resistidos para \\ idosas sarcopênicas: estudo quase-experimental
}

Efecto de un programa de ejercicios resistidos para ancianas sarcopénicas: estudio cuasiexperimental

\author{
Joana Ude Viana ${ }^{[a]}$, João Marcos Domingues Dias ${ }^{[a]}$, Patrícia Parreira Batista ${ }^{[a]}$, \\ Sílvia Lanziotti de Azevedo Silva ${ }^{[\mathrm{b}]}$, Rosângela Corrêa Dias ${ }^{[a]}$, Lygia Paccini Lustosa ${ }^{[\mathrm{a}]^{*}}$
}

[a] Universidade Federal de Minas Gerais (UFMG), Belo Horizonte, MG, Brazil

[b] Universidade Federal de Alfenas (UNIFAL), Alfenas, MG, Brazil

\begin{abstract}
Introduction: Resistance training is quoted as one of the best pathways to manage sarcopenia and progressive resistance training is supposed to improve muscle mass, strength and performance in older adults. Objective: The aim was to examine the impact of a progressive resistance exercise program (PREP) on muscle and function performance in sarcopenic community-dwelling elder women. Methods: Quasiexperimental study (pre - post intervention). Participated 18 sarcopenic community-dwelling elder women (65 years or older). PREP based on 75\% of the participant's maximum load (12/wk, 3 times/wk). Main
\end{abstract}

\footnotetext{
"JUV: PhD, e-mail: joana_ude@yahoo.com.br JMDD: PhD, e-mail: jmdd@eeffto.ufmg.com PPB: Doctoral student, e-mail: patriciaparreira@gmail.com

SLAS: PhD, e-mail: silviafisiojf@yahoo.com.br

RCD: PhD, e-mail: rcd@ufmg.br

LPL: PhD, e-mail: llustosa@ufmg.br
} 
outcome measures: muscle strength of knee extensors (isokinetic dynamometry), muscle mass (dual-x ray absorptiometry - DXA), functional performance (Short Physical Performance Battery - SPPB). Paired t-test was used to evaluate differences pre and post intervention. Results: Improvements on power $(p=0.01)$ and peak torque $(\mathrm{p}=0.01)$ were observed when measured by the isokinetic dynamometer at low speed $(60 \mathrm{o} / \mathrm{s})$. Improvements on DXA (pre PREP: $5.49 \mathrm{~kg} / \mathrm{m} 2$ vs. post PREP: $6.01 \mathrm{~kg} / \mathrm{m} 2 ; \mathrm{p}=0.03$ ) and SPPB scores (pre PREP: 9.06 vs. post PREP: 10.28; $p=0.01$ ) were also observed. Conclusion: The PREP was able to improve muscle and functional performance in sarcopenic community-dwelling elder women. This program should be considered in clinical practice.

Keywords: Aged. Rehabilitation. Resistance Training. Sarcopenia.

\section{Resumo}

Introdução: Exercícios com carga são uma das boas indicações de tratamento no caso da sarcopenia e o treinamento com carga progressiva pode aumentar a massa muscular, força e desempenho em idosos. Objetivo: Avaliar o impacto de um programa de exercícios com carga progressiva (PECP) no desempenho muscular e funcional de idosas sarcopênicas da comunidade. Métodos: Estudo quasi-experimental (pré-pós intervenção). Participaram 18 idosas sarcopênicas, da comunidade (65 anos e mais). PECP foi baseado em 75\% de uma resistência máxima (12/semanas, 3 x/ semana). Medidas de desfecho: força muscular dos extensores de joelho (dinamômetro isocinético), massa muscular (dual-x ray absorptiometry - DXA), desempenho funcional (Short Physical Performance Battery - SPPB). Comparações pré-pós intervenção foi por meio do teste t-test pareado. Resultados: Houve aumento na potência $(p=0,01)$ e no torque $(p=0,01)$, observados nas medidas do isocinético em baixa velocidade (60\%/s). Observou-se também aumento no DXA $(5,49 \mathrm{~kg} / \mathrm{m} 2 \mathrm{vs} .6,01 \mathrm{~kg} / \mathrm{m} 2 ; p=0,03) e$ melhora nos escores do SPPB (9,06 vs. 10,28; $p=0,01)$. Conclusão: $O$ PECP aumentou o desempenho funcional $e$ muscular das idosas sarcopênicas comunitárias. Este programa deve ser considerado para a prática clínica.

Palavras-chave: Idoso. Reabilitação. Sarcopenia. Treinamento de Carga.

\section{Resumen}

Introducción: Ejercicios con carga es una de las buenas indicaciones de tratamiento en el caso de la sarcopenia y el entrenamiento con carga progresiva puede aumentar la masa muscular, fuerza y desempeño en ancianos. Objetivo: Evaluar el impacto de un programa de ejercicios con carga progresiva (PECP) en el desempeño muscular y funcional de ancianas sarcopénicas de la comunidad. Métodos: Estudio cuasiexperimental (prepos intervención). Participaron 18 ancianas sarcopénicas, de La comunidad (65 años y más). PECP se basó en $75 \%$ de una resistencia máxima (12/semanas, $3 \mathrm{x} /$ semana). Las medidas de desenlace: fuerza muscular de los extensores de rodilla (dinamómetro isocinético), masa muscular (dual-x ray absorptiometry - DXA), desempeño funcional (Short Physical Performance Battery - SPPB). Las comparaciones pre-post-intervención fueron a través de La prueba t-test pareado. Resultados: Hubo aumento en la potencia $(p=0,01)$ y en el par de apriete - torque $(p=0,01)$, observados en las medidas del isocinético a baja velocidad (60\%/s). Se observo también un aumento en el DXA $\left(5,49 \mathrm{~kg} / \mathrm{m}^{2} v s .6,01 \mathrm{~kg} / \mathrm{m}^{2}, p=0,03\right)$ y mejora en los escores del SPPB $(9,06 \mathrm{vs}$. 10,28, $p=0,01$. Conclusión: El PECP aumento el desempeño funcional y muscular de las ancianas sarcopénicas comunitarias. Este programa debe ser considerado para la práctica clínica.

Palabras clave: Ancianas. Entrenamiento de Carga. Rehabilitación. Sarcopenia. 


\section{Introduction}

In 1989, Irving Rosenberg [1] stated that no loss is more devastating for older adult people than muscle mass decline which usually decreases about $1 \%$ /year [2 - 4]. Muscle strength losses are even higher, reaching an incidence of $3 \% / y e a r$ and is usually more pronounced in lower limbs leading to important functional disabilities [5], being also extremely influenced by lifestyle and chronic conditions [6]. These functional disabilities are usually related to the difficulty of walking, balance and carrying out activities of daily living. However, no linear relation has been seen between muscle mass and force decline $[7,8]$. At this moment, the literature points that strength loss usually precedes muscle mass losses [7]. On the other hand, a longitudinal study has shown that changes in muscle mass could predict improving in muscle strength [5], demonstrating that there are still controversies in this area.

Recently, a group of researchers [7] have termed this condition as sarcopenia and proposed its screening based on muscle mass, muscle strength and physical performance. Individuals over 65 years old who present reduced muscle mass are considered pre-sarcopenic, those with associated low muscle strength or decreased performance are sarcopenic, and individuals combining changes on these three parameters are severe sarcopenic. Its prevalence vary hugely depending on the instrument used to assess muscle mass [8 - 10] and many studies have shown numbers between 5 to $50 \%$ $[7,11,12]$. Sarcopenia is now recognized as a geriatric syndrome [10] and is related to important disabilities [13] and elevated healthcare costs [14].

Due to the magnitude of the adverse outcomes on the elder's independence, quality of life and the increased burden on health systems, diverse possible strategies to prevent and/or treat sarcopenia have been developed along the years. Despite nutritional, hormonal and pharmacological resources [15], resistance training is quoted as one of the best pathways to manage sarcopenia. Morphological and functional adaptations to resistance exercise have been well described in literature [16] and progressive resistance training is supposed to improve neuromuscular changes, muscle strength, muscle mass and performance in older adults $[17,18]$. Despite the evidence of the benefits of resistance exercise, there are still few studies with populations under specific health conditions. This way, no studies have shown the effects of resistance training on sarcopenia profile, classified according to the European Working Group on Sarcopenia in Older People (EWGSOP). Therefore, the aim of the present study was to evaluate the effects of a progressive resistance exercise program on lean mass, muscle and functional performance of sarcopenic community-dwelling older adult women.

\section{Methods}

This was a quasi-experimental study (pre/post intervention) approved by the Research Ethics Committee under the number 36571814.1.0000.5149. Participants were recruited verbally at an outpatient unit of an Older Adult Care Reference Hospital and if accepted to participate, signed an informed consent prior to enrollment in the study. First, all subjects were assessed for cognitive impairment using the Mini Mental State Examination [19]. If screened negative according to schooling level, they were then evaluated for sarcopenia according to the algorithm proposed by the European Working Group on Sarcopenia in Older People [7] (Figure 1). Subjects classified as sarcopenic (low muscle mass associated to low muscle strength and/ or decreased physical performance) were then enrolled to the intervention group.

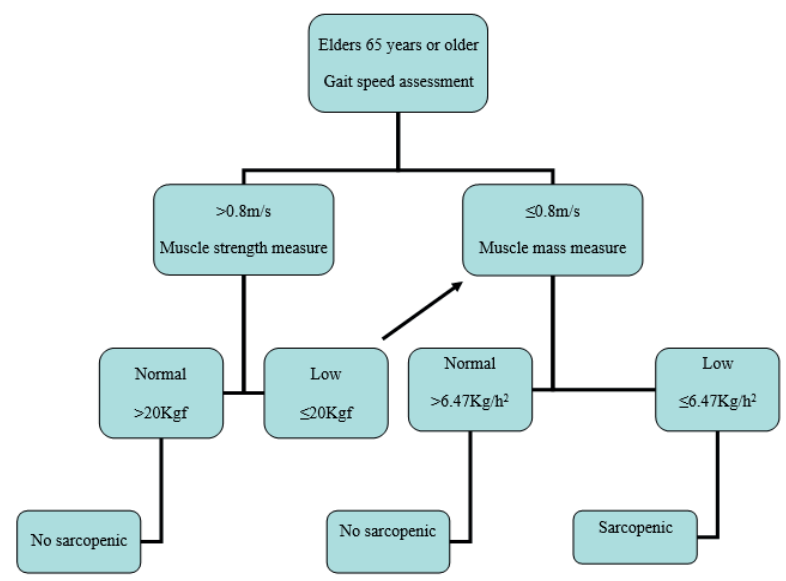

Figure 1 - EWSOP suggested algorithm for sarcopenia case finding in older individuals - Adapted from Cruz-Jentoft et al. [7].

\section{Participants}

To be included in the study, subjects must be 65 years or older and should be classified as sarcopenic according to the EWGSOP [7] (muscle mass: dual x-ray absorptiometry, muscle strength: handgrip dynamometry and physical performance: Short Physical Performance Battery). Exclusion criteria 
were cognitive impairment [19], physical disabilities that could impair functional tests, sequelae of stroke, Parkinson's disease, rheumatic diseases, recent hand surgeries, cancer and/or chemotherapy treatment and in use of corticosteroids.

Muscle strength

Muscle strength of knee extensors was evaluated on the dominant leg by an isokinetic dynamometer Biodex System 4 Pro ${ }^{\circledR}$ (Biodex Systems, Shirley - New York, USA), at angular velocities of $60^{\circ} / \mathrm{s}$ and $180^{\circ} / \mathrm{s}$, using five repetitions for the lower velocity and fifteen repetitions for the higher one. This was the same protocol used before by researchers with older adults [20]. Verbal motivation was given to the participant during all test protocol. For analyses, variables were normalized by body weight.

\section{Body lean mass}

It was assessed through dual x-ray absorptiometry (DXA), Hologic Discovery software 3.3.0 (Hologic, Inc., Marlborough - Massachussets, USA), this is a noninvasive low-radioactive and low-cost imaging resource that allows the measurement of fat-mass, fat-free mass and bone mineral density. It can estimate appendicular lean mass through the sum of upper and lower limbs muscle mass, adjusted by height square, measure that has been widely used in sarcopenia research [7,21]. Cut-off points for Brazilian older adults muscle mass are still not well established in literature using a method like DXA, but a cross-sectional study have demonstrated good correlation between estimate equations and densitometry [22]. In this way, the cut-off point for DXA was established previously in a population-based study with Brazilian older adults using Lee's equation (not published data - cited with author's permission), and it was considered positive (low muscle mass) if under $6.47 \mathrm{~kg} / \mathrm{m} 2$.

\section{Functional performance}

Functional performance was evaluated by the Short Physical Performance Battery (SPPB), an objective multifunctional instrument used to assess functional capacity through three domains: balance (feet side-byside, semi-tandem and tandem positions), gait speed (time spent to walk a four-meter course) and indirect lower limbs strength (five times chair sit-to-stand test). A total of 12 points can be scored, being higher values indicative of lower disability [23].

\section{Intervention}

The progressive resistance exercise program (PREP) was conducted over a period of 12 weeks, three sessions/ week and duration of an hour with small groups of four or five elder under the guidance of trained physical therapists. The sessions were divided into three stages. First, ten minutes of lower limbs stretching exercises (hips and knees flexors and extensors, triceps surae - three times of 30 seconds each side). Second, 40 minutes of strengthening exercises using knee extension and flexion, hip extension and flexion, hip abduction and bridge hip plus hip abduction using a ball and semi-squat. Ankle weights were used to perform the exercises with oneminute interval between the three sets of 12 repetitions each. The last stage consisted of 10 minutes cool down exercises. For knees flexors and extensors, exercises were performed using $75 \%$ of the subject's maximal load and were reassessed every two weeks according to a previously published protocol $[20,24]$.

\section{Statistical analysis}

Descriptive statistical analysis was conducted through absolute and relative frequencies for categorical data, means and standard deviation for the continuous variables. Data normality was confirmed by Kolmogorov-Smirnov test. Paired t-test was used to evaluate differences pre and post intervention for the following variables: SPPB score, isokinetic dynamometer (total work, peak torque, fatigue and power) and DXA. The significance level considered was $5 \%$ and the confidence interval 95\%, all analysis was performed with SPSS 16.0 for Windows.

\section{Results}

Eighteen sarcopenic community-dwelling older adult women with mean age of $75.11( \pm 3.67)$ years were enrolled in this study. Ten of them were widows and 11 mixed races. The most prevalent chronic 
diseases were cataract (11 of them), hypertension (10 of them), and six reported arthrosis. Other comorbidities are listed in Table 1.

Table 1- Sociodemographic and clinical characteristics of the sarcopenic elder women

\begin{tabular}{|c|c|}
\hline Characteristics & $\mathrm{n}=18$ \\
\hline Age, years, means (SD) & $75.11(7.19)$ \\
\hline \multicolumn{2}{|l|}{ Race } \\
\hline White, number (\%) & $4(22.20)$ \\
\hline Mixed race, number (\%) & $11(61.10)$ \\
\hline \multicolumn{2}{|l|}{ Marital status } \\
\hline Married, number (\%) & $4(22.20)$ \\
\hline Widowed, number (\%) & $10(55.60)$ \\
\hline Years of education, means (SD) & $3.67(2.59)$ \\
\hline \multicolumn{2}{|l|}{ Comorbidities } \\
\hline Cataract, number (\%) & $11(61.10)$ \\
\hline Hypertension, number (\%) & $10(55.60)$ \\
\hline Arthrosis, number (\%) & $6(35.30)$ \\
\hline Labirintitis, number (\%) & $6(33.30)$ \\
\hline Diabetes, number (\%) & $2(11.10)$ \\
\hline Heart problems, number (\%) & $3(16.70)$ \\
\hline Self-reported depression, number (\%) & $10(55.60)$ \\
\hline Falls in the previous year, number (\%) & $7(38.90)$ \\
\hline \multicolumn{2}{|l|}{ Nutritional Status } \\
\hline Under nutritional risk (MNA*), number (\%) & $11(61.10)$ \\
\hline
\end{tabular}

Note: *Mini Nutritional Assessment.

Lean mass measured by DXA, showed significant ( $\mathrm{p}=0.03$; power $=0.90)$ improvements of about $0.52 \mathrm{~kg} / \mathrm{h} 2$ after the PREP. Only power $(p=0.01$; power $=0.98)$ and peak torque $(p=0.01$; power $=0.96)$ at $60 \mathrm{o} / \mathrm{s}$ were statistically significant. Significant changes were also seen for SPPB scores ( $p=0.01$; power $=0.97)$ after intervention (Table 2).

Table 2 - Muscle and functional performance variables values at baseline and post PREP

(to be continued)

\begin{tabular}{|c|c|c|c|c|c|c|}
\hline Variables & $\begin{array}{l}\text { Pre-intervention } \\
\text { mean (SD) }\end{array}$ & $\begin{array}{l}\text { Post intervention } \\
\text { mean (SD) }\end{array}$ & $T$ test & $\begin{array}{c}\text { Paired } \\
\text { samples test - } \\
\text { sig (2-tailed) }\end{array}$ & Power & $\begin{array}{l}\text { Effect } \\
\text { Size** }\end{array}$ \\
\hline \multirow{2}{*}{\multicolumn{7}{|c|}{$\begin{array}{l}\text { Muscle strength } \\
\text { Isokinetic dynamometry }\left(60^{\circ} / \mathrm{s}\right)\end{array}$}} \\
\hline & & & & & & \\
\hline Total work (J) & 254.27 (52.90) & $280.45(79.43)$ & -2.03 & 0.06 & 0.48 & 0.28 \\
\hline Power (Watts) & $32.46(7.95)$ & $38.03(9.60)$ & -4.26 & $0.01^{*}$ & 0.98 & 0.63 \\
\hline
\end{tabular}




\begin{tabular}{|c|c|c|c|c|c|c|}
\hline Variables & $\begin{array}{c}\text { Pre-intervention } \\
\text { mean (SD) }\end{array}$ & $\begin{array}{l}\text { Post intervention } \\
\text { mean (SD) }\end{array}$ & T test & $\begin{array}{c}\text { Paired } \\
\text { samples test - } \\
\text { sig (2-tailed) }\end{array}$ & Power & $\begin{array}{l}\text { Effect } \\
\text { Size**}\end{array}$ \\
\hline Peak torque (Nm) & $48.30(11.83)$ & $73.37(75.57)$ & -3.97 & $0.01^{*}$ & 0.96 & 0.28 \\
\hline Fatigue (\%) & $11.02(25.57)$ & $18.51(11.63)$ & -1.52 & 0.15 & 0.30 & 0.23 \\
\hline \multicolumn{7}{|c|}{ Isokinetic dynamometry $\left(180^{\circ} / \mathrm{s}\right)$} \\
\hline Total work (J) & $480.32(99.68)$ & $512.96(124.52)$ & -1.36 & 0.19 & 0.25 & 0.20 \\
\hline Power (Watts) & $46.59(10.82)$ & $50.97(13.47)$ & -1.60 & 0.13 & 0.32 & 0.36 \\
\hline Peak torque $(\mathrm{Nm})$ & $28.06(6.03)$ & $30.14(6.85)$ & -1.47 & 0.16 & 0.28 & 0.16 \\
\hline Fatigue (\%) & $18.21(13.79)$ & $22.51(20.36)$ & -1.04 & 0.32 & 0.16 & 0.25 \\
\hline DXA $\left(\mathrm{Kg} / \mathrm{h}^{2}\right)$ & $5.49(0.68)$ & $6.01(0.63)$ & -3.45 & $0.01 *$ & 0.90 & 0.79 \\
\hline SPPB & $9.06(2.43)$ & $10.28(2.16)$ & -4.11 & $0.01^{*}$ & 0.97 & 0.53 \\
\hline
\end{tabular}

Note: statistically significant at $p<0.05$; ${ }^{*}$ statistically significant difference after intervention; PREP (Progressive Resistance Exercise Program); DXA (dual x-ray absorptiometry); SPPB (Short Physical Performance Battery); Nm (Newton x meters); J (Joules); ${ }^{* *}$ Cohen $\mathrm{d}_{\mathrm{m}}$ for paired samples.

\section{Discussion}

The aim of this study was to examine the impact of PREP on muscle and function performance in sarcopenic community-dwelling elder women. After the 12 weeks, positive changes were observed in body lean mass, muscle strength and physical performance. A meta-analysis corroborates the findings of this study, particularly in the increase of muscle mass [17]. Similarly, another recent meta-analysis [25] also showed gains in muscle size in all 15 included studies, being higher loads improvements better than light to moderate program (11\% vs. $9 \%)$. Churchward-Venne et al. [26] have recently demonstrated after a resistance-type exercise training that lean mass increased by $0.9 \pm 0.1 \mathrm{~kg}(\mathrm{p}<0.001)$ from 0 to 12 weeks, reinforcing the idea that this kind of intervention can promote significant changes in body lean mass. Probably these changes occurred due to the fact that there was greater muscular stimulation, increasing the demand for fiber recruitment [27 - 29]. This stimulus may have been effective for the recruitment of fibers, especially type I, due to the difference in muscle strength (peak torque) demonstrated at low speed $(60 \mathrm{o} / \mathrm{s})$. The literature indicates that in the physiology of muscle contraction, during the evaluation by isokinetic, slower speeds tend to demonstrate more strength probably due to the greater recruitment of type I fibers [28 - 33].

In this case, positive changes were seen for quadriceps strength after the PREP, especially improvement on peak torque and power at $60^{\circ} / \mathrm{s}$. These results demonstrated that training at $75 \%$ was able to recruit motor units and in this case, probably type I fibers, which are more evident in sarcopenic subjects. However, in the future, further studies to verify the actual recruitment of the fibers are required. In addition, the intervention used in this study did not involve velocity training and improvements in higher speeds were not expected. In sarcopenia there is predominance of type I fibers and greater loss of type II fibers. This loss entails, indirectly, loss of function. However, it is still unclear the relationship of gains and losses to muscle strength and function [29 - 32]. In this study, the fact that there is increase in strength, muscle mass and muscle function suggests that there may be a relationship between these. This specific strengthening program was sufficient to increase these variables in sarcopenic community-dwelling elder women, reinforcing the fact that 12 weeks of training, with $75 \%$ loading, is sufficient for these women.

On the other hand, research has shown that gains of approximately $1.1 \mathrm{~kg}$ in lean mass could reduce the time to perform walking and stair climb tests and that $1 \mathrm{~kg}$ increasing in fat mass could add about 1 second to conclude 5 times sit to stand test, indicating that gains in lean mass can enhance physical performance [33]. Although the gains in lean mass were lower than those reported by the authors, the results demonstrated here pointed to an improvement in function as well. These findings reinforce the presented results and point out to a possible relation between muscle mass, strength and functionality improvements. However, the influence and strength of these parameters relation must be studied in future researches. In this case, it is suggested to consider the use of larger samples, especially for those variables 
that the size of the effect had smaller magnitude, observed in the present investigation.

Finally, the results concerning strength training and improvements in function measured by SPPB are also in accordance to other studies results [33]. Positive significant changes were also seen in functional capacity measured by SPPB. Mean score significantly increased indicating that improvements in lean mass and muscle strength were accompanied by a better functional performance. These findings are congruent to the results of Gennuso et al. [31] that showed significant differences between control and intervention groups after a resistance training program for total SPPB scores and muscle strength for older adults with reduced physical abilities.

\section{Study limitations}

This study has some limitations related to its non-controlled and non-randomized design, what impairs to establish cause-effect relationship. On the other hand, the great power values achieved showed that the sample size was enough to reinforce intervention effectiveness. As sarcopenia is a multifactorial syndrome, other variables not controlled in this study should be investigated in future researches as possible confounders or interrelated components such as frailty, nutrition, supplementation and behavioral status. Individual variability should also be taken into consideration as ageing and the adaptive responses to intervention are heterogeneous events.

\section{Conclusion}

The Progressive Resistance Training Program was able to counteract losses on muscle mass, strength and physical performance in community-dwelling sarcopenic older adults and this kind of exercise could be used safely to avoid the negative impact of the loss of strength and muscle mass on sarcopenia.

\section{Acknowledgments}

This study was sponsored by Pró-Reitoria de Pesquisa da Universidade Federal de Minas Gerais; Conselho Nacional de Desenvolvimento Científico e Tecnológico (CNPq); Fundação de Amparo à Pesquisa do Estado de Minas Gerais (FAPEMIG) and Coordenação de Aperfeiçoamento de Pessoal de Nível Superior (CAPES).

\section{References}

1. Rosenberg IH. Summary Comments. Am J Clin Nutr. 1989;50(5):1231-3.

2. Frontera WR, Hughes VA, Fielding RA, Fiatarone MA, Evans WJ, Roubenoff R. Aging of skeletal muscle: a 12-yr longitudinal study. JAppl Physiol (1985). 2000;88(4):1321-6.

3. Goodpaster BH, Park SW, Harris TB, Kritchevsky SB, Nevitt M, Schwartz AV, et al. The loss of skeletal muscle strength, mass and quality in older adults: the health, aging and body composition study. J Gerontol A Biol Sci Med Sci. 2006;61(10):1059-64.

4. Frontera WR, Reid KF, Philips EM, Krivickas LS, Hughes VA, Roubenoff R, et al. Muscle fiber size and function in elderly humans: a longitudinal study. J Appl Physiol (1985). 2008;105(2):637-42.

5. Hughes VA, Frontera WR, Wood M, Evans WJ, Dallal GE, Roubenoff R, et al. Longitudinal muscle strength changes in older adults: influence of muscle mass, physical activity, and health. J Gerontol A Biol Sci Med Sci. 2001;56(5):B209-17.

6. Stenholm S, Tiainen K, Rantanen T, Sainio P, Heliövaara M, Impivaara 0, etal. Long-term determinants of musclestrength decline: prospective evidence from the 22-year Mini-Finland follow-up survey. J Am Geriatr Soc. 2012;60(1):77-85.

7. Cruz-Jentoft AJ, Baeyens JP, Bauer JM, Boirie Y, Cederholm T, Landi F, et al. Sarcopenia: European Working Group on definition and diagnosis: report of the European Working Group on Sarcopenia in Older People. Age Ageing. 2010;39(4):412-23. 
8. Bijlsma AY, Meskers CGM, Ling CHY, Narici M, Kurrle SE, Cameron ID, etal. Defining sarcopenia: the impact of different diagnostic criteria on the prevalence of sarcopenia in a large middle aged cohort. Age (Dordr). 2013;35(3):871-81.

9. Coin A, Sarti S, Ruggiero E, Giannini S, Pedrazzoni M, MinisolaS, etal. Prevalence of sarcopenia based on different diagnostic criteria using DEXA and appendicular skeletal muscle mass reference values in an Italian population aged 20 to 80. J Am Med Dir Assoc. 2013;14(7):507-12.

10. Cruz-Jentoft AJ, Landi F, Topinkóva E, Michel JP. Understanding sarcopenia as a geriatric syndrome. Curr Opin Clin Nutr Metab Care. 2010;13(1):1-7.

11. LeeWJ,LiuLK,PengLN,Lin MH,ChenLK;ILASResearch Group. Comparison of sarcopenia defined by IWGS and EWGSOP criteriaamongolderpeople:resultsfrom theI-LanLongitudinal Aging Study. J Am Med Dir Assoc. 2013;14(7):528.e1-e7.

12. Cruz-Jentoft AJ, Landi F, Schneider SM, Zúñiga C, Arai $\mathrm{H}$, Boirie Y, et al. Prevalence and interventions for sarcopenia in ageing adults: a systematic review. Report of the International Sarcopenia Initiative (EWGSOP and IWGS). Age Ageing. 2014;43(6):748-59.

13. Woo J, Leung J, Sham A, Kwok T. Defining sarcopenia in terms of risk of physical limitations: a 5-year follow-up study of 3.153 chinese men and women. J Am Geriatr Soc. 2009;57(12):2224-31.

14. Janssen I, Shepard DS, Katzmarzyk PT, Roubenoff R. The healthcare costs of sarcopenia in the United States. J Am Geriatr Soc. 2004;52(1):80-5.

15. Waters DL, Baumgartner RN, Garry PJ, Vellas B. Advantages of dietary, exercise-related, and therapeutic interventions to prevent and treat sarcopenia in adult patients: an update. Clin Interv Aging. 2010;5:259-70.

16. Nicastro H, Zanchi NE, Luz CR, Lancha Jr AH. Functional and morphological effects of resistance exercise on disuse-induced skeletal muscle atrophy. Braz J Med Biol Res. 2011;44(11):1070-9.

17. Peterson MD, Sen A, Gordon PM. Influence of resistance exercise on lean body mass in aging adults: a metaanalysis. Med Sci Sports Exerc. 2011;43(2):249-58.

18. Sundell J. Resistance training is an effective tool against metabolic and frailty syndromes. Adv Prev Med. 2011;2011:ID984683.
19. Bertolucci PHF,Brucki SM, Campacci SR, Juliano YS. The minimental state examination in a general population: impact of educational status. Arq Neuropsiquiatr. 1994;52(1):1-7.

20. Lustosa LP, Coelho FM, Silva JP, Pereira DS, Parentoni AN, Dias JM, et al. The effects of a muscle resistance program on the functional capacity, knee extensor muscle strength and plasma levels of IL- 6 and TNF-alpha in pre-frail elderly women: a randomized crossover clinical trial a study protocol. Trials. 2010;11:82.

21. Cawthon PM. Assessment of Lean Mass and Physical Performance in Sarcopenia. J Clin Densitom. 2015;18(4):467-71.

22. Alexandre TS, Duarte YA, Santos JL, Wong R, Lebrão LM. Prevalence and associated factors of sarcopenia among elderly in Brazil: findings from the SABE study. J Nutr Health Aging. 2014;18(3):284-90.

23. Guralnik JM, Simonsiki EM, Ferrucci L, Glynn RJ, Berkman LF, Blazer DG, et al. A short physical performance battery assessing lower extremity function: association with self-reported disability and prediction of mortality and nursing home admission. J Gerontol. 1994;49(2):M85-94.

24. Lustosa LP, Pereira LSM, Coelho FM, Pereira DS, Silva JP, Parentoni AN, et al. Impact of an exercise program on muscular and functional performance and plasma levels of interleukin 6 and soluble receptor tumor necrosis factor in prefrail community-dwelling older women: a randomized controlled trial. Arch Phys Med Rehabil. 2013;94(4):660-6.

25. Csapo R, Alegre LM. Effects of resistance training with moderate vs heavy loads on muscle mass and strength in the elderly: a meta-analysis. Scand J Med Sci Sports. 2016;26(9):995-1006.

26. Churchward-Venne TA, Tieland M, Verdijk LB, Leenders M, Dirks ML, de Groot LC, et al. There are no nonresponders to resistance-type exercise training in older men and women. J Am Med Dir Assoc. 2015;16(5):400-11.

27. Martins WR, Safons MP, Bottaro M, Blasczyk JC, Diniz LR, Fonseca RMC, et al. Effects of short term elastic resistance training on muscle mass and strength in untrained older adults: a randomized clinical trial. BMC Geriatr. 2015;15:99. 
28. Henwood TR, Riek S, Taaffe DR. Strength versus muscle power-specific resistance training in communitydwelling older adults. J Gerontol A Biol Sci Med Sci. 2008;63(1):83-91.

29. Beneka A, Malliou P, Fatouros I, Jamurtas A, Gioftsidou A, Godolias G, et al. Resistance training effects on muscular strength of elderly are related to intensity and gender. J Sci Med Sport. 2005;8(3):274-83.

30. Van Roie E, Delecluse C, Cadyzen W, Boomen S, Bautmans I. Strength training at high versus low external resistence in older adults: effects on muscle volume, muscle strength, and force-velocity characteristics. Exp Gerontol. 2013;48(11):1351-61.

31. Gennuso KP, Zalewski K, Cashin SE, Strath SJ. Resistance training congruent with minimal guidelines improves function in older adults: a pilot study. J Phys Act Health. 2013;10(6):769-76.
32. Zech A, Drey M, Freiberger E, Hentschke C, Bauer JM, Sieber CC, et al. Residual effects of muscle strength and muscle power training and detraining on physical function in community-dwelling prefrail older adults: a randomized controlled trial. BMC Geriatr. 2012;12:68.

33. Liu CK, Leng X, Hsu FC, Kritchevsky SB, Ding J, Earnest $\mathrm{CP}$, et al. The impact of sarcopenia on a physical activity intervention: the Lifestyle Interventions and Independence for Elders Pilot Study (LIFE-P). J Nutr Health Aging. 2014;18(1):59-64.

Received in 11/05/2017

Recebido em 05/11/2017

Approved in 03/14/2018

Aprovado em 14/03/2018 